Terbit online pada laman web jurnal: http://jurnal.iaii.or.id

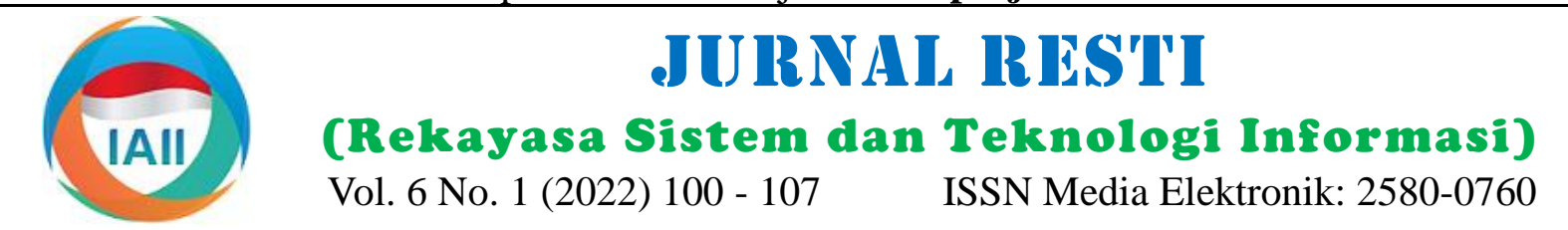

\title{
Sistem Pengukuran Suhu Tubuh Menggunakan AMG8833 Dan Kinect Sebagai Pencegahan Penularan Covid-19
}

\author{
Wiwin Lovita ${ }^{1}$, Aulia $^{2}$, Junaldi $^{3}$ \\ ${ }^{1,2}$ Teknik Elektro, Universitas Andalas \\ ${ }^{3}$ Teknik Elektro, Politeknik Negeri Padang \\ ${ }^{1}$ uwinlovita199607@gmail.com, ${ }^{2}$ aulia@eng.unand.ac.id, ${ }^{3}$ junaldi@pnp.ac.id
}

\begin{abstract}
The purpose of this study is to create an effective and safe body temperature measurement system to prevent the transmission of covid-19 using the AMG8833 and Kinect. The method of sending data uses the Internet of Thing (IoT) and face tracking with $3 D$ form as face identification using a kinect type xbox 360 using an arduino uno and a buzzer connected to the AMG8833. AMG8833 has an infrared detector which is arranged in an $8 \times 8$ array and reads body temperature non-contact by detecting infrared energy from the body. kinect recognizes facial features based on the distance of the kinect position coordinates on the face. AMG8833 and kinect as input, Arduino uno as AMG8833 data processing and buzzer gives a sound signal if the temperature is above $37.10^{\circ} \mathrm{C}$. Body temperature measurement data was carried out 3 times, namely at a distance of 5,10 and $15 \mathrm{~cm}$. Measurement data from this body temperature measuring instrument are compared with a thermogun average error value of $0.11 \%$ with a difference between the maximum and minimum average body temperatures of 0.04\%. It is hoped that body temperature measurements can be as a precaution against the spread of covid-19.
\end{abstract}

Keywords: AMG8833, kinect, arduino uno, buzzer, face tracking, internet of thing

\begin{abstract}
Abstrak
Pada masa pandemi covid-19, pemerintahan indonesia menetapkan kebijakan tentang protokol kesehatan (prokes) bagi masyarakat untuk mencegah semakin meluasnya penularan covid-19. Salah satu prokes yang harus dilakukan adalah mengukur suhu tubuh. Tujuan penelitian ini membuat sistem pengukuran suhu tubuh secara efektif dan aman dilakukan sebagai pencegahan penularan covid-19 menggunakan sensor AMG8833 dan kinect. Metode pengiriman data menggunakan Internet Of Thing (IoT) dan face tracking bentuk 3D sebagai identifikasi wajah pada kinect tipe xbox 360. AMG8833 memiliki inframerah detektor yang disusun secara array 8x8 dari sebuah sensor thermopile dengan menggunakan teknologi MEMS (Micro Electro Mechanical System) dan membaca suhu tubuh secara non-kontak dengan mendeteksi energi inframerah dari tubuh. Kinect sebagai input mengenali fitur wajah pada objek berdasarkan titik-titik wajah melalui sistem koordinat jarak kinect dengan wajah sebagai memasukan data pengguna secara otomatis. Hasil deteksi wajah melalui titik tersebut antara lain terletak di dahi, sisi wajah sebelah kanan dan kiri, dagu, serta titik tengah hidung. AMG8833 sebagai input pengukuran suhu tubuh, arduino uno sebagai pemprosesan data AMG8833 dan buzzer memberikan tanda bunyi jika suhu diatas $37.10^{\circ} \mathrm{C}$. Pengukuran suhu tubuh menggunakan AMG8833 dilakukan sebanyak 3 kali pengukuran yaitu pada jarak 5,10, dan $15 \mathrm{Cm}$. Hasil pengukuran suhu tubuh menggunakan AMG8833 dibandingkan dengan pengukuran menggunakan thermogun dan didapatkan nilai ratarata error sebesar $0,11 \%$ dengan selisih rata-rata suhu tubuh maksimal dan minimum sebesar $0,04 \%$. Pengukuran suhu tubuh ini diharapkan dapat dilakukan sebagai pencegahan penularan covid-19.
\end{abstract}

Kata kunci: AMG8833, kinect, arduino, buzzer, face tracking, internet of thing

\section{Pendahuluan}

Pada masa pandemi covid-19 [1], pemerintahan indonesia telah menetapkan peraturan kesehatan (prokes) bagi masyarakat sebagai upaya pencegahan penularan covid-19 dengan melakukan pengukuran suhu tubuh dan menerapkan aturan tentang protokol jaga jarak atau physical distancing [2]. Penularan covid-19 diawali dari seseorang yang terinfeksi covid19 kepada orang lain disekitarnya melalui droplet yaitu percikan bersin atau batuk [3]. Selanjudnya penularan diketahui melalui percikan batuk atau bersin seseorang yang terkontaminasi dengan benda-benda yang disentuh seseorang tersebut lalu menyentuh mata,

Diterima Redaksi: 06-12-2021 | Selesai Revisi: 21-02-2022 | Diterbitkan Online: 27-02-2022 
hidung dan mulut [4]. Menurut han \& yang (2020), tentang diagnosis covid-19 Jarak tetesan yang dihembuskan ke udara yang lembab dan hangat ketika seseorang batuk atau bersin yang sangat keras menyebar hingga 8,2 meter (27 kaki). Dalam kondisi tertentu, virus di dalam droplet dapat bertahan di udara hingga 45 menit, pada kulit beberapa menit serta pada pakaian dan masker hingga 12 jam [5].

Pengukuran suhu tubuh menjadi suatu hal yang penting pada masa pandemi covid-19 ketika seseorang diharuskan untuk keluar rumah atau melakukan suatu aktivitas seperti ke kantor, ke mal membeli kebutuhan harian dll [6]. Dalam dunia kesehatan, alat pengukuran suhu tubuh umumnya menggunakan termometer. Cara penggunaan termometer dengan diselipkan ke ketiak atau ke dalam mulut selama 3-5 menit. Penggunaan termometer berbentuk tabung dari kaca rentan pecah dan menimbulkan kekhawatiran jika terjadinya infeksi nosokomial karena adanya kontak langsung dengan tubuh [7].

Beberapa penelitian telah membuat alat pengukuran suhu tubuh, Alvianto Wahyu Pribadi (2013) melakukan penelitian tentang alat pengukur suhu tubuh digital skala celcius dengan keluaran suara digunakan bagi orang yang mengalami keterbatasan dalam penglihatan (tunanetra). Perangkat keras alat ini terdiri dari sensor suhu LM35, Mikrokontroler ATMega16, LCD 16x2 (cm), dan ISD25120. Tegangan keluaran dari sensor diubah menjadi data digital oleh ADC, diproses oleh mikrokontroller dan ditampilkan data pada yang akan diikuti oleh keluaran suara. Alat ini telah terealisasi dan dapat mengukur suhu tubuh pada skala celcius dengan keluaran suara pada ketelitian pembacaan $0,1^{\circ} \mathrm{C}[8]$.

Meilia dan Gusti (2019), melakukan penelitian mengenai non-kontak termometer berbasis inframerah sebagai cara untuk mengatasi penyebaran bakteri stafilokokus dan VRE. Pada penelitian ini dirancang sebuah termometer infrared menggunakan sensor MLX90614 dan arduino nano V3 sebagai main kontroller, untuk menampilkan data digunakan LCD serta dilengkapi dengan indikator buzzer yang terhubung pada kontroller. Sistem ini memiliki tingkat presisi dan akurasi diatas 96\% [9]. Abdul dan Frada (2020), penelitian ini merancang alat pengukuran suhu tubuh berdasarkan jarak pengukuran sensor pada tubuh. Nilai pembacaan suhu tubuh yang akurat berdasarkan nilai galat (error) yang didapatkan menggunakan sensor MLX90614 yang dipadukan dengan ESP32-CAM serta LCD TFT. Dari sistem ini diketahui bahwa semakin jauh jarak pengukuran maka akan semakin besar nilai galatnya [10].

Rindi Wulandari (2020) melakukan penelitian rancang bangun alat pengukur suhu tubuh berbasis arduino memiliki alarm pengingat jika suhu tubuh berada diatas angka 37.30 dan terhubung ke perangkat komputer melalui bluetooth. Alat pengukur suhu tubuh ini dibuat sebagai pencegahan penularan covid-19 dan melakukan perbandingan pengukuran suhu tubuh menggunakan thermogun. Penelitian ini memanfaatkan sensor DS18B20 untuk mengukur suhu dalam satuan celcius. Data suhu tubuh juga ditampilkan pada LCD 16x2 (cm). Hasil pengujian alat pengukuran suhu tubuh ini dibandingkan dengan thermogun dan memiliki rentang penyimpangan $1.16 \%$ sampai $2.02 \%$ [11].

Menurut penelitian Unang Achlison (2020) tentang Analisis Implementasi Pengukuran Suhu Tubuh Manusia dalam Pandemi Covid-19 di Indonesia, penelitian ini membahas tentang perbandingan nilai ukur sensor suhu tubuh manusia pada alat ukur suhu berbasis microcontroller terhadap variasi jenis sensor suhu yang digunakan yaitu sensor suhu LM35 pada penelitian Alvianto Wahyu Pribadi (2013), sensor suhu infrared MLX90614 pada penelitian Meilia dan Gusti (2019) dan sensor suhu DS18B20 pada penelitian Rindi Wulandari (2020). Penelitian ini dilakukan analisa perbandingan nilai hasil pengukuran yang dihasilkan dari variasi jenis sensor suhu yang digunakan dan akan ditetapkan mana yang lebih akurat dan efisien dalam hasil pengukuran suhu tubuh manusia. Sensor LM35 lebih efisien dan akurat bila digunakan dengan cara ditempelkan pada dahi maupun ketiak tubuh manusia dengan rata-rata persentase 0,49. Sensor MLX90614 dan DS18B20 lebih efisien dan akurat bila digunakan dengan berjarak $2 \mathrm{~cm}-1 \mathrm{~cm}$ diarahkan pada muka maupun tangan tubuh manusia dengan rata-rata persentase 0,64 dan 1,18 [12].

Berdasarkan keputusan Menteri Kesehatan RI No. HK.01.07/MENKES/382/2020, Salah satu langkah menghentikan penularan virus korona bagi pekerja atau karyawan diluar rumah dengan melakukan pengukuran suhu tubuh menggunakan thermogun [13]. Penggunaan thermogun diarahkan kedahi membutuhkan operator untuk mengoperasikan dengan Jarak pengukuran antara $2 \mathrm{~cm}$ sampai $12 \mathrm{~cm}$. Sekarang ini hampir semua tempat seperti mall, tepat ibadah, bandara, kantoran, rumah sakit, tempat sekolah dan lainnya menggunakan thermogun untuk mengukur suhu tubuh sebagai upaya pencegahan penularan covid-19. Prinsip kerja thermogun yaitu menangkap energi radiasi yang terpancar dari tubuh manusia diolah dan menghasilkan data suhu berbentuk angka digital yang terdapat pada layar thermogun [14].

Dari beberapa penelitian tersebut, penggunaan sensor LM35, MLX90614 dan DS18B20 belum efektif dilakukan dalam pencegahan covid-19 karena sensor suhu tersebut belum dikatakan akurat terlihat dari ratarata persentase perbandingan penggunaan sensor dan LCD 16x2 (cm) hanya menampilkan data suhu tubuh saja tanpa mengenali identitas seseorang yang melakukan pengukuran suhu tubuh tersebut. Penggunaan thermogun yang dilakukan dengan 
diarahkan ke dahi tersebut juga belum dikatakan aman karena masih dilakukan secara manual dengan membutuhkan operator mengoperasikannya sehingga berpeluang tertularnya covid-19 melalui udara ketika seseorang bersin atau batuk.

Dengan demikian, penelitian ini bertujuan membuat sistem pengukuran suhu tubuh secara efektif dan aman dilakukan terlihat dari keakuratan sensor yang digunakan serta dapat mengenali seseorang yang melakukan pengukuran suhu tubuh. Penelitian ini menggunakan sensor AMG8833 dan kinect tipe xbox 360 didapatkan data dalam bentuk angka suhu tubuh dan gambar seseorang sebagai pencegahan penularan covid-19. Menurut WHO, normal suhu tubuh adalah $36^{\circ} \mathrm{C}$ sampai $37^{\circ} \mathrm{C}$. Pada umumnya suhu di pagi hari sekitar $36^{\circ} \mathrm{C}$, sedang pada malam hari $37^{\circ} \mathrm{C}$ dan jika suhu besar dari $37,1^{\circ} \mathrm{C}$ maka suhu dikatakan tidak normal dan harus dilakukan pemantauan [15].

Penggunaan AMG8833 sebagai pengukuran suhu tubuh memiliki inframerah detektor yang disusun secara array $8 \times 8$ dari sebuah sensor thermopile dengan menggunakan teknologi MEMS (Micro Electro Mechanical System) dan membaca suhu tubuh secara non-kontak dengan mendeteksi energi inframerah dari tubuh. Menurut Nishi, dkk (2017), AMG8833 bekerja dengan menangkap pantulan inframerah dari wien (benda hitam) dan menangkap amplitudo atau panjang gelombang dari sensor radiasi suhu tubuh manusia sekitar $10 \mu \mathrm{m}$. Range pembacaan AMG8833 dari $0^{\circ} \mathrm{C}$ hingga $80^{\circ} \mathrm{C}$ memiliki akurasi pembacaan $\pm 2,5^{\circ} \mathrm{C}$ dengan 7 meter jarak pengukuran dari objek [16]. Melalui akurasi pembacaan dan jarak penggunaan AMG8833 pada objek lebih akurat jika dibandingkan dengan alat pengukuran suhu tubuh lainnya sebagai pencegahan penularan covid-19.

Pembacaan sensor pada objek yang dilakukan melalui pemanfaatan $8 \times 8$ piksel resolusi. Piksel resolusi AMG8833 menyajikan data nilai suhu melalui pembacaan inframerah berdasarkan banyaknya data pembacaan nilai suhu sebanyak 64 titik dari AMG8833 yang digunakan. Nilai suhu tubuh resolusi dari piksel tersebut disimpan pada arduino uno untuk dilakukan pengolahan nilai dari sensor. Arduino Uno sebagai pengolahan data AMG8833 (ADC) melalui proses nilai input dilakukan pada IDE arduino software dan ditampilkan data suhu pada serial monitor serta buzzer memberikan tanda bunyi ketika suhu melebihi suhu normal, agar petugas atau security dapat melakukan tindakan selanjudnya.

Kinect diterbitkan November 2010 dan aplikasi Windows pada Februari 2012. Microsoft merilis Kinect Software Development Kit (Kinect SDK) dapat digunakan para pengembang piranti lunak untuk mengembangkan aplikasi menggunakan kinect. Kinect memiliki fitur-fitur yang meliputi kamera RGB, depth sensor atau sensor kedalaman, dan multi-array michrophone. Depth sensor merupakan fitur yang berperan dalam membedakan kinect dengan kamera. Depth memiliki kombinasi dari infrared laser projector dan monochrome CMOS sensor yang mengambil data gambar dalam 3D tanpa memperdulikan kondisi cahaya. Kamera RGBD pada kinect dapat bekerja dengan baik pada kondisi horizontal viewing angle: $57^{\circ}$, Vertical viewing angle: $43^{\circ}$, dan memiliki depth range: 400mm (near mode) sampai $8000 \mathrm{~mm}$ (standard mode). Jarak terbaik penggunaan kinect adalah 1.2 meter sampai 4 meter dari objek [17].

Penggunaan kinect sangat aman dilakukan dalam pembacaan wajah melalui deteksi titik-titik area wajah berdasarkan sistem koordinat antara jarak kinect ke wajah dengan menggunakan metode Face Tracking. Hasil deteksi wajah melalui titik tersebut antara lain terletak di dahi, sisi wajah sebelah kanan dan kiri, dagu, serta titik tengah hidung. Infrared pada kinect tidak dapat dilihat secara kasat mata serta tidak berbahaya bagi tubuh manusia. Infrared mengirimkan ribuan sinar yang memantul untuk mengetahui objek yang berada didepannya. Sinar yang dihasilkan oleh infrared inilah yang ditangkap oleh kamera monochrome CMOS sensor dan mengukur waktu sinar yang ada setelah terpantul oleh objek dan menjadikan kinect sebagai memetakan gambar 3D dengan kedalaman $1 \mathrm{~cm}$ dan $3 \mathrm{~mm}$ untuk lebar dan tinggi [18].

\section{Metode Penelitian}

Metode penelitian ini memiliki jenis terapan melalui metode eksperimental yang dilakukan. Adapun langkah dari metode ini adalah melakukan rancangan hardware, rancangan software serta melakukan analisis metode yang digunakan sebagai identifikasi wajah seseorang dalam melakukan pengukuran suhu tubuh.

\subsection{Rancangan Hardware}

Sebagai langkah awal dalam pembuatan sistem pengukuran suhu tubuh, terlebih dahulu dibuat perancangan hardware yang terdiri dari blok diagram dari sebuah sistem. Blok diagram rancangan hardware terlihat pada Gambar 1.

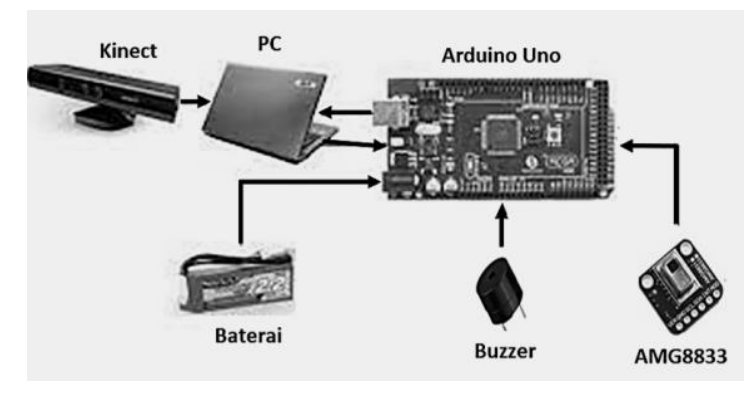

Gambar 1. Blok Diagram Rancangan Hardware

Pada Gambar 1 tersebut, rancangan hardware yang diperoleh meliputi blok diagram dari komponen tambahan yang digunakan pada alat yang akan 
dirancang. Sistem yang akan dibuat memiliki beberapa komponen yang harus disediakan diantaranya sensor AMG8833 dan kinect tipe xbox 360 sebagai input, arduino uno sebagai pengolahan data input terhubung pada PC sebagai tempat melakukan pemograman data yang terhubung pada baterai sebagai catu daya. Buzzer dan tampilan data pada PC dijadikan output hasil data. Buzzer memberikan tanda bunyi ketika suhu melebihi suhu normal $(>37,2)$.

\subsection{Rancangan Software}

Perangkat lunak terdiri dari software IDE (Integrated Developtment and Environment) melalui hubungan perangkat arduino uno yang digunakan berdasarkan pemograman bahasa C. Software IDE berguna untuk tampilan nilai input sensor AMG8833 dan terlihat pada serial monitor. Hasil program data suhu tersebut dilakukan editor teks bentuk sketch yang penyimpanan bentuk file adalah ekstensi.ino. Gambar 2 berikut adalah proses pembacaan suhu tubuh menggunakan sensor AMG8833.

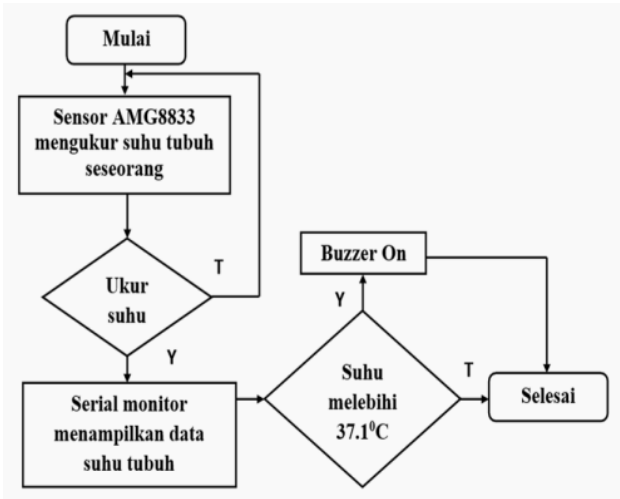

Gambar 2. Diagram Alir Pembacaan Suhu Tubuh

Pada Gambar 2 diatas, Pembacaan suhu tubuh dilakukan dengan diarahkan tepat pada dahi dengan jarak 5, 10 dan $15 \mathrm{~cm}$. Pembacaan sensor dilakukan dengan mengubah energi listrik atau sinyal listrik yang terpancar dari tubuh yang telah didapatkan kemudian dikonversi ke dalam bentuk sinyal digital menggunakan Analog to Digital Converter (ADC). Selanjutnya sinyal digital tersebut masuk ke dalam sistem kontrol untuk dilakukan penghitungan, perbandingan dan koreksi sehingga menghasilkan output sudah dalam bentuk suhu dengan satuan derajat celcius $\left({ }^{\circ} \mathrm{C}\right)$. Data suhu tubuh tersebut terlihat pada serial monitor pengujian pada software IDE. Jika suhu melebihi suhu normal atau besar dari $37,1^{\circ} \mathrm{C}$ maka buzzer berbunyi agar petugas atau security dapat melakukan tindakan selanjunya.

Dalam penelitian ini, proses identifikasi wajah yang dilakukan menggunakan kinect terhadap pengguna menggunakan software Microsoft Kinect [19]. Proses identifikasi wajah dari perangkat lunak dapat di ilustrasikan pada Gambar 3. Proses diawali dari pengguna membaca wajah orang yang melakukan pengukuran suhu tubuh dengan inisialisasi point wajah berdasarkan deteksi gerakan kepala. Untuk proses mengetahui derajat arah pergerakan kepala berdasarkan asumsi total derajat gerakan kepala kekanan kekiri 180 derajat. Hasil deteksi wajah yang berhasil ditangkap kinect kemudian diolah agar diketahui titik - titik wajah yang akan dideteksi. Titik tersebut antara lain terletak di dahi, sisi wajah sebelah kanan dan kiri, dagu, serta titik tengah hidung. Kinect menampilkan pengenalan titik wajah yang menggunakan metode Face Tracking sehingga memungkinkan wajah yang tertangkap dapat diambil dan diolah datanya.

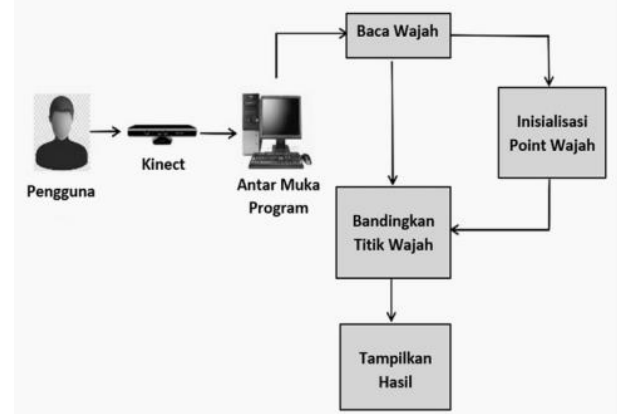

Gambar 3. Proses Identifikasi Wajah

\subsection{Metode Face Tracking}

Identifikasi wajah menggunakan metode face tracking dengan Windows SDK, yaitu software yang telah tersedia pada Microsoft Kinect dengan membaca wajah manusia secara real time. Windows SDK membaca titik wajah menggunakan sistem koordinat Kinect untuk menampilkan hasil deteksi 3D [20]. Gambar 4 berikut adalah sistem koordinat kinect deteksi wajah.

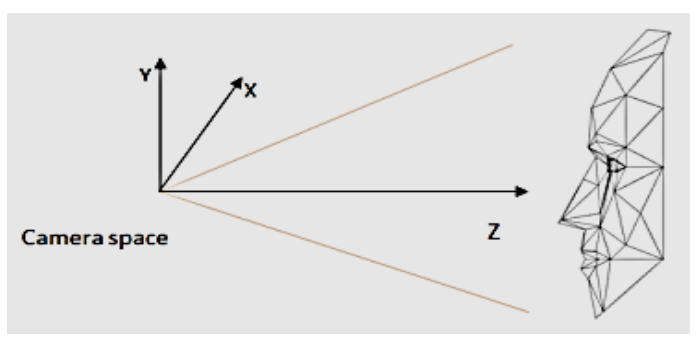

Gambar 4. Sistem koordinat dari SDK deteksi Wajah

Kinect terletak didepan wajah minimal 1,2 meter dari wajah. Kamera space (sensor), sumbu $\mathrm{Z}$ mengarah ke objek, sumbu Y mengarah ke atas. Satuan pengukuran adalah meter untuk translasi dan derajat untuk sudut rotasi. Deteksi wajah dalam bentuk 3D dihitung melalui sistem koordinat yang penempatannya lurus dengan wajah [21]. Untuk memulai pembacaan wajah, perlu mengenali titik-titik wajah yang akan dideteksi. Titiktitik ini didefinisikan dalam ruang koordinat gambar RGB (dalam resolusi 640 x 480) yang dikembalikan dari sensor Kinect. Posisi X, Y dan Z dari kepala objek didapatkan berdasarkan sistem koordinat tangan kanan (titik asal pada sensor, $\mathrm{Z}$ menunjuk ke arah objek dan $\mathrm{Y}$

DOI: https://doi.org/10.29207/resti.v6i1.3687

Lisensi: Creative Commons Attribution 4.0 International (CC BY 4.0) 
menunjuk ke atas, ini sama dengan kerangka koordinat kerangka Kinect) dan pose kepala objek ditangkap oleh tiga sudut yaitu pitch, roll dan yaw. Sudut dinyatakan dalam derajat dengan nilai berkisar dari -180 derajat hingga +180 derajat [22].

Pemancar sinar inframerah (IR) dari sensor Kinect memproyeksikan gelombang ini ke lingkungan di sekitarnya berdasarkan sudut view $43^{\circ}$ vertikal dan $57^{\circ}$ horisontal [23]. Objek yang terpapar gelombang ini akan memantulkan IR kembali. Pantulan IR dari obyek penghalang tertangkap sensor kamera depth. Jarak antara kamera dengan lingkungan sekitarnya diperhitungkan dari berkas IR yang dipantulkan objek penghalang [24]. Proses akuisisi data dengan KinectSDK berhasil menangkap dan menampilkan deteksi titik kerangka wajah dari pembacaan area titiktitik tersebut meliputi: bagian tengah mata, sudut mulut, bagian tengah hidung dan kotak pembatas di sekitar kepala telihat pada Gambar 5 dibawah ini.

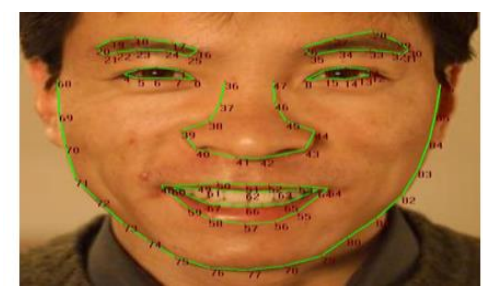

Gambar 5. Pembacaan Titik Wajah SDK Kinect

\section{Hasil dan Pembahasan}

Hasil penelitian ini menyajikan pengujian sensor AMG8833 dan kinect dengan mengidentifikasi wajah seseorang yang melakukan pengukuran suhu tubuh dan membandingkan data suhu tubuh menggunakan AMG8833 dengan thermogun sebagai alat pengukuran suhu tubuh sebagai pencegahan penularan covid-19 sekarang ini.

\subsection{Pengujian Sensor Kinect}

Kinect tipe xbox360 berfungsi sebagai identifikasi wajah seseorang yang melakukan pengukuran suhu tubuh. Dengan melakukan identifikasi wajah menggunakan Kinect dapat diketahui seseorang melakukan pengukuran suhu tubuh. Pengujian sensor kinect tipe xbox 360 dilakukan dengan dua kali pengambilan data dalam bentuk 2D (wajah awal) dan 3D (face tracking). Algoritma komputasi bentuk wajah bergantung pada data kedalaman dan titik wajah 2D. Gambar 6 berikut adalah wajah awal bentuk 2D.

Oleh karena itu jika beberapa area wajah tertutup oleh rambut atau sesuatu yang lain dan terlihat secara mendalam, maka perhitungan menghasilkan bentuk yang berubah untuk area tersebut. Kamera RGBD pada kinect memiliki noise temporal dan sistematis kinect saat menghitung jarak ke wajah manusia. Algoritma deteksi wajah dengan metode face tracking model 3D linier untuk menghitung pose kepala 3D, dan koefisien animasi 3D.

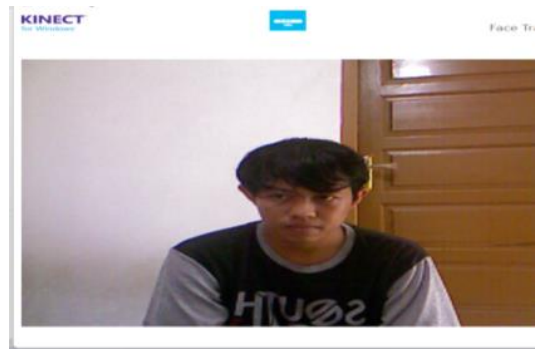

Gambar 6. Wajah Awal Bentuk 2D

Skala pada kepala untuk mengetahui konstan titik objek wajah objek tertentu selama waktu pembacaan wajah. Pada bagian ini menjelaskan cara menghitung parameter bentuk dan menginisialisasi model 3D. dengan memulai mengetahui titik wajah baru dengan model 3D yang diinisialisasi ke wajah rata-rata (skala diatur ke 1,0 dan disetel ke 0). Gambar 7 berikut adalah bentuk 3D data wajah menggunakan metode face tracking.

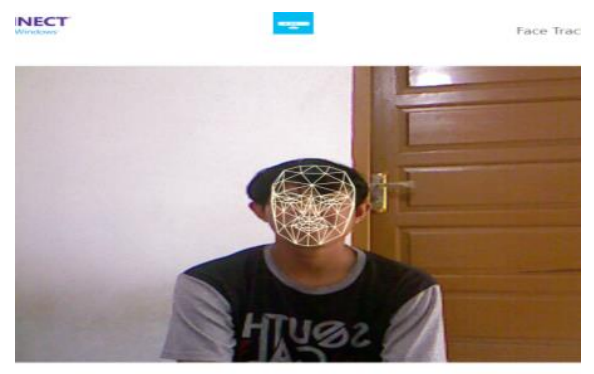

Gambar 7. Face Tracking Wajah 3D

Kinect mengumpulkan hasil pembacaan titik wajah dan data input RGBD untuk frame yang berhasil dideteksi. Kami meminta objek hanya menunjukkan wajah netral tanpa emosi selama waktu ini. Selama melakukan pembacaan titik objek, kinect dapat mengurangi pengaruh ekspresi pada perhitungan bentuk wajah. Misalnya, ekspresi seperti senyum lebar dapat mempengaruhi geometri daerah mulut. Untuk memaksimalkan hasil data yang makximal pengguna harus melihat lurus ke kamera, memutar kepala ke kiri dan ke kanan sebesar $30^{\circ}$ dan melihat ke atas dan ke bawah sebesar $15^{\circ}$. Proses ini diperlukan untuk mengumpulkan data yang lebih beragam dan menghilangkan noise.

\subsection{Pengujian Sensor AMG8833}

Setelah dilakukan identifikasi pada wajah dilakukan pengukuran suhu tubuh menggunakan AMG8833. Cara pengukuran yaitu dengan meletakkan atau mengarahkan sensor AMG8833 pada dahi dan menunggu dengan jangka waktu 1 menit lalu akan terlihat data nilai suhunya dengan 1 pengambilan data sebanyak 7 objek pembacaan suhu tubuh seseorang terlihat pada Gambar 8 dibawah ini. 


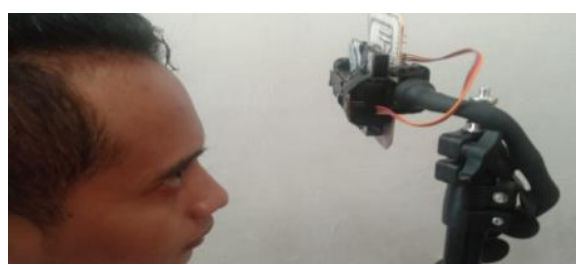

Gambar 8. Cara Pengukuran Suhu Tubuh dengan AMG8833

Tabel 1. Data Pengukuran Suhu Tubuh Menggunakan AMG8833

\begin{tabular}{lllll}
\hline $\begin{array}{l}\text { Orang } \\
\text { Ke- }\end{array}$ & $\begin{array}{l}\text { Jarak } \\
5 \mathrm{Cm}\end{array}$ & $\begin{array}{l}\text { Jarak } \\
10 \mathrm{Cm}\end{array}$ & $\begin{array}{l}\text { Jarak } \\
15 \mathrm{Cm}\end{array}$ & $\begin{array}{l}\text { Rata- } \\
\text { rata }\end{array}$ \\
\hline 1 & $36,77^{0} \mathrm{C}$ & $36,78^{0} \mathrm{C}$ & $36,75^{\circ} \mathrm{C}$ & $36,77^{0} \mathrm{C}$ \\
2 & $36,66^{0} \mathrm{C}$ & $36,64^{0} \mathrm{C}$ & $36,59^{0} \mathrm{C}$ & $36,62^{0} \mathrm{C}$ \\
3 & $36,64^{0} \mathrm{C}$ & $36,63^{\circ} \mathrm{C}$ & $36,62^{\circ} \mathrm{C}$ & $36,63^{0} \mathrm{C}$ \\
4 & $36,89^{0} \mathrm{C}$ & $36,91^{\circ} \mathrm{C}$ & $36,99^{\circ} \mathrm{C}$ & $36,93^{0} \mathrm{C}$ \\
5 & $37,02^{\circ} \mathrm{C}$ & $37,05^{\circ} \mathrm{C}$ & $37,00^{\circ} \mathrm{C}$ & $37,02^{\circ} \mathrm{C}$ \\
6 & $37,17^{0} \mathrm{C}$ & $37,16^{\circ} \mathrm{C}$ & $37,13^{\circ} \mathrm{C}$ & $37,15^{0} \mathrm{C}$ \\
7 & $36,80^{\circ} \mathrm{C}$ & $36,79^{\circ} \mathrm{C}$ & $36,76^{\circ} \mathrm{C}$ & $36,78^{0} \mathrm{C}$ \\
\hline
\end{tabular}

Berdasarkan Tabel 1 tersebut, didapatkan hasil pengukuran suhu tubuh menggunakan AMG8833 dengan diarahkan pada dahi berdasarkan jarak pengukuran $5,10,15 \mathrm{~cm}$ dari 7 orang sebagai objek pengukuran. Dari pengukuran suhu tubuh didapatkan orang ke- 6 memiliki suhu tubuh tertinggi dengan ratarata $37,15^{\circ} \mathrm{C}$. Pengukuran suhu tubuh memiliki nilai yang berubah-ubah atau mengalami perubahan nilai berdasarkan jarak yang di ukur. Untuk jarak yang lebih akurat didapatkan pengukuran suhu dengan jarak 10Cm. Respon suhu tubuh berdasarkan jarak pengukuran nilainya tidak jauh berbeda sekitar error rata-rata 1 sampai $3 \%$.

\subsection{Hasil Identifikasi Wajah}

Proses identifikasi wajah dengan kinect dimulai pada saat pengguna memulai program dan wajah pengguna berhasil dibaca. Program akan memanggil modul face tracking milik Microsoft Kinect kemudian diolah, dan hasilnya ditampilkan dengan menandai Setelah berhasil dibaca, maka wajah pengguna akan ditandai dengan pembacaan titik area wajah di proses dalam bentuk 3D melalui sistem koordinat jarak deteksi kinect pada area wajah. Setelah titik wajah diinisiasikan maka dilakukan gerakan kepala disebut ke kanan, ke kiri, tengah maupun ke atas sebagai deteksi 3D face tracking. Dari hasil pengujian didapatkan data akuisisi data pada Windows SDK berhasil menangkap dan menampilkan deteksi titik kerangka wajah dari pembacaan area titiktitik tersebut meliputi: bagian tengah mata 8 titik, sudut mulut 12 titik, bagian tengah hidung 13 titik, dan di sekitar kepala 21 titik. Dari titik tersebut didapatkan pengenalan wajah berdasarkan biodata objek terlihat pada Gambar 9 berikut.

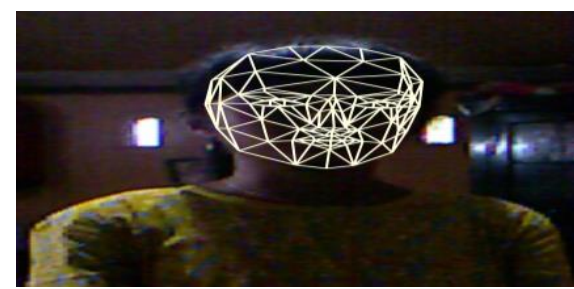

Gambar 9. Identifikasi Wajah 3D Face Tracking

\subsection{Hasil Perbandingan Data Suhu Tubuh}

Pengujian ini membandingkan nilai suhu tubuh yang telah diukur menggunakan AMG8833 dengan nilai suhu tubuh dari pengukuran thermogun pada jarak $10 \mathrm{~cm}$. Hasil pengujian sistem terlihat pada Tabel 2. Pengujian keakuratan sensor AMG8833 berdasarkan perbandingan data suhu nilai rata-rata AMG8833 dengan thermogun yang dipakai dengan mendapatkan nilai galat atau error berdasarkan Persamaan 1 dibawah ini.

$$
\text { Galat }(\text { error })=\frac{A V-T V}{A V} \times 100 \%
$$

dengan AV atau ACTUAL VALUE merupakan data suhu dari objek dilakukan pengukuran dari thermogun untuk perbandingan data suhu, TV atau TEST VALUE merupakan data nilai dari sensor AMG8833 dengan pembacaan berdasarkan objek sebelumnya dari thermogun.

Tabel 2. Perbandingan Hasil Pengukuran Suhu Tubuh Menggunakan AMG8833 dan Thermogun

\begin{tabular}{lllllll}
\hline $\begin{array}{l}\text { Orang } \\
\text { ke- }\end{array}$ & $\begin{array}{l}\text { Kamera Thermal } \\
\left({ }^{\circ} \mathrm{C}\right)\end{array}$ & $\begin{array}{l}\text { Thermogun } \\
\left({ }^{0} \mathrm{C}\right)\end{array}$ & $\begin{array}{l}\text { Selisih } \\
\left({ }^{0} \mathrm{C}\right)\end{array}$ & $\begin{array}{l}\text { Error } \\
(\%)\end{array}$ & Kondisi & Keterangan \\
\hline 1 & 36,77 & 36,7 & 0,07 & 0,19 & Normal & Buzzer Off \\
2 & 36,62 & 36,6 & 0,02 & 0,05 & Normal & Buzzer Off \\
3 & 36,63 & 36,6 & 0,03 & 0,08 & Normal & Buzzer Off \\
4 & 36,93 & 36,9 & 0,03 & 0,08 & Normal & Buzzer Off \\
5 & 37,02 & 37,1 & 0,08 & 0,21 & Normal & Buzzer Off \\
6 & 37,15 & 37,2 & 0,05 & 0,13 & Tidak Normal & Buzzer On \\
7 & 36,78 & 36,8 & 0,02 & 0,05 & Normal & Buzzer Off \\
\hline Rata-rata & 36,84 & 36,84 & 0,04 & 0,11 & & \\
\hline
\end{tabular}

Berdasarkan Tabel 2, terlihat variasi nilai suhu tubuh memakai sensor AMG8833 mendapatkan tingkat nilai yang berbeda dari nilai yang menggunakan thermogun. Selisih data suhu tubuh antara kamera thermal dan thermogan didapatkan rata-rata $0,04^{\circ} \mathrm{C}$ dengan selisih terendah $0,02^{\circ} \mathrm{C}$ untuk orang ke 7 dan 2 , hingga tertinggi $0,08^{\circ} \mathrm{C}$ untuk orang ke 5 . Pengukuran suhu menggunakan thermogun ketika mencapai 37,2 
dikatakan tidak normal karena termasuk dalam pemantauan sedangkan pada AMG8833 memiliki suhu $37,15{ }^{0} \mathrm{C}$. Berikut adalah grafik perbandingan nilai pengukuran suhu tubuh yang dilakukan menggunakan AMG8833 dan thermogun sebagai pencegahan penularan covid-19. Pada orang ke-4 memliki suhu tubuh sebesar $37,2^{\circ} \mathrm{C}$ menggunakan thermogun sedangkan pada AMG8833 sebesar $37,15^{\circ} \mathrm{C}$ untuk nilai error sebesar $0,13 \%$. Dari data itu didapatkan kesimpulan yakni suhu tubuh diatas $37,10^{\circ} \mathrm{C}$ menggunakan kamera thermal dikategorikan tidak normal dan suhu tubuh normal sekitar $36,00^{\circ} \mathrm{C}$ hingga $37,00^{\circ} \mathrm{C}$.

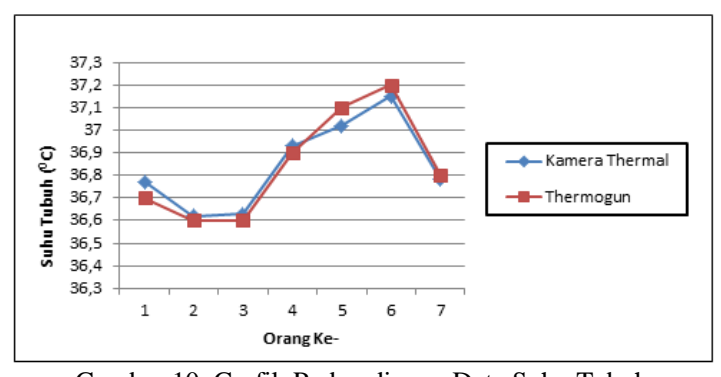

Gambar 10. Grafik Perbandingan Data Suhu Tubuh

Berdasarkan Gambar 10, menunjukkan perbedaan perbandingan data suhu tubuh menggunakan AMG8833 untuk grafik biru dan thermogun untuk grafik merah. Nilai error yang diperoleh berkisar antara $0,05 \%$ sampai $0,21 \%$. Nilai error tersebut didapatkan rata-rata $0,11 \%$ dari 7 objek pengukuran. Hasil pengukuran suhu tubuh tertinggi terdapat pada orang ke-4 dengan nilai error 0,21\% dinyatakan kondisi suhu tubuh tidak normal dan perlu dilakukan tinjauan maka buzzer memberikan tanda bunyi (on) agar security atau petugas dapat melakukan tindakan selanjudnya. Nilai suhu tubuh yang didapatkan tersebut memiliki batas toleransi dari penggunaan sensor tersebut dan nilai eror yang didapatkan sangat berguna dalam pembacaan suhu dari tubuh yang dilakukan sebagai pencegahan penularan covid-19 ini.

Beberapa penelitian telah melakukan pengujian sensor untuk mengukur suhu tubuh manusia. Sensor yang digunakan beberapa penelitian untuk mengukur suhu tubuh diantaranya LM35, MLX90614 dan DS18B20. Penggunaan sensor tersebut memiliki perbedaan keakuratan penggunaan pada masa pendemi. Berikut adalah hasil perbandingan keakuratan penggunaan sensor untuk mengukur suhu tubuh manusia dari beberapa penelitian.

Tabel 3. Hasil Ukur Keakuratan Sensor LM35, MLX90614, DS18B20 dan AMG8833

\begin{tabular}{lllll}
\hline $\begin{array}{l}\text { Nama } \\
\text { Sensor Suhu }\end{array}$ & $\begin{array}{l}\text { Rata-rata } \\
\text { Thermometer } \\
\text { Standard }\end{array}$ & $\begin{array}{l}\text { Rata-rata } \\
\text { Hasil Ukur }\end{array}$ & $\begin{array}{l}\text { Rata-rata } \\
\text { Selisih }\end{array}$ & $\begin{array}{l}\text { Rata-rata } \\
\text { Persentase }\end{array}$ \\
\hline LM35 & $32,00^{\circ} \mathrm{C}$ & $32,17^{0} \mathrm{C}$ & $0,17^{0} \mathrm{C}$ & $0,49^{0} \mathrm{C}$ \\
MLX90614 & $35,50^{\circ} \mathrm{C}$ & $35,55^{\circ} \mathrm{C}$ & $0,23^{0} \mathrm{C}$ & $0,64^{0} \mathrm{C}$ \\
DS18B20 & $37,00^{\circ} \mathrm{C}$ & $36,86^{\circ} \mathrm{C}$ & $0,44^{0} \mathrm{C}$ & $1,17^{0} \mathrm{C}$ \\
AMG8833 & $36,84^{\circ} \mathrm{C}$ & $36,84^{0} \mathrm{C}$ & $0,04^{0} \mathrm{C}$ & $0,11^{\circ} \mathrm{C}$ \\
\hline
\end{tabular}

Berdasarkan Tabel 3 diatas, rata-rata persentase hasil ukur sensor suhu untuk mengukur suhu tubuh manusia menghasilkan hasil ukur yang mendekati hasil ukur thermometer standart. Pada masa pandemic covid-19 ini thermometer standart yang digunakan adalah thermogun.

\section{Kesimpulan}

Berdasarkan dari perbandingan nilai suhu tubuh pengujian AMG8833 dan thermogun didapatkan ratarata persentase $0,11 \%$. Perbandingan hasil pengukuran suhu tubuh tersebut sangat efektif dan akurat dibandingkan dari beberapa penelitian menggunakan Sensor MLX90614 dan DS18B20 dengan jarak 10cm diarahkan pada dahi terlihat pada Tabel 3 hasil ukur perbandingan keakuratan pengukuran suhu tubuh. Sensor LM35 lebih efisien dan akurat bila digunakan dengan cara ditempelkan pada dahi maupun ketiak tubuh manusia. Sensor MLX90614 dan DS18B20 lebih efisien dan akurat bila digunakan dengan berjarak $2 \mathrm{~cm}$ diarahkan pada muka maupun tangan tubuh manusia, namun jarak tersebut dapat berpeluan covid-19 jika tidak diwaspadai. Sebagai identifikasi wajah seseorang yang melakukan engukuran suhu tubuh didapatkan agar sistem mengenali wajah seseorang. Optimasi pembacaan suhu tubuh yang dilakukan dengan mengenali wajah seseorang, yang dibahas dalam penelitian ini fokus pada jangkauan jarak sistem koordinat face tracking betuk 3D yang dapat dibaca sensor. Sudut view $43^{\circ}$ vertikal dan $57^{\circ}$ horizontal merupakan batasan yang menarik untuk dikembangkan sehingga dapat dicapai view yang meliputi keseluruhan arah (omnidirectional).

\section{Daftar Rujukan}

[1] F. Freni et al., "Symptomatology in head and neck district in coronavirus disease (COVID-19): A possible neuroinvasive action of SARS-CoV-2," Am. J. Otolaryngol. - Head Neck Med. Surg., vol. 41, no. 5, p. 102612, 2020, doi: 10.1016/j.amjoto.2020.102612.

[2] C. Ceraolo and F. M. Giorgi, "Genomic variance of the 2019nCoV coronavirus," J. Med. Virol., vol. 92, no. 5, pp. 522-528, 2020, doi: 10.1002/jmv.25700.

[3] G. Vasantharao and S. Arifunneesa, "Temperature Detection and Automatic Sanitization and Disinfection Tunnel-COVID 19," Int. J. Anal. Exp. modal Anal., vol. XII, no. VI, pp. 1175-1181, 2020.

[4] T. Singhal, "A Review of Coronavirus Disease-2019 (COVID19)," Indian J. Pediatr., vol. 87, no. 4, pp. 281-286, 2020, doi: 10.1007/s12098-020-03263-6.

[5] Y. Han and H. Yang, "The transmission and diagnosis of 2019 novel coronavirus infection disease (COVID-19): A Chinese perspective," J. Med. Virol., vol. 92, no. 6, pp. 639-644, 2020, doi: $10.1002 / j m v .25749$

[6] A. Susilo et al., "Coronavirus Disease 2019: Tinjauan Literatur Terkini,” J. Penyakit Dalam Indones., vol. 7, no. 1, p. 45, 2020, doi: 10.7454/jpdi.v7i1.415.

[7] W. Widhiada, I. N. G. Antara, I. N. Budiarsa, and I. M. G. Karohika, "The Robust PID Control System of Temperature Stability and Humidity on Infant Incubator Based on Arduino at Mega 2560," IOP Conf. Ser. Earth Environ. Sci., vol. 248, no. 1, 2019, doi: 10.1088/1755-1315/248/1/012046. 
[8] A. Pribadi, "Prototipe Termometer Digital Dengan Keluaran Suara Berbasis Mikrokontroler Atmega16," Inov. Fis. Indones., vol. 2, no. 03, pp. 11-13, 2013.

[9] M. Safitri and G. A. Dinata, "Non-Contact Thermometer Berbasis Infra Merah," Simetris J. Tek. Mesin, Elektro dan Ilmu Komput., vol. 10, no. 1, pp. 21-26, 2019, doi: 10.24176/simet.v10i1.2647.

[10]A. H. Kuspranoto and F. O. Sinaga, "Monitoring Suhu Tubuh dengan Output Suara Berbasis ESP-32CAM," Med. Tek. J. Tek. Elektromedik Indones., vol. 3, no. 1, 2021, doi: 10.18196/mt.v3i1.11980.

[11]R. Wulandari, "Rancang Bangun Pengukur Suhu Tubuh Berbasis Arduino Sebagai Alat Deteksi Awal Covid-19," Pros. SNFA (Seminar Nas. Fis. dan Apl., vol. 5, pp. 183-189, 2020, doi: 10.20961/prosidingsnfa.v5i0.46610.

[12]U. Achlison, "Analisis Implementasi Pengukuran Suhu Tubuh Manusia dalam Pandemi Covid-19 di Indonesia," J. Ilm. Komput. Graf., vol. 13, no. 2, pp. 102-106, 2020, [Online]. Available: https://journal.stekom.ac.id/index.php/pixel/article/view/318.

[13]U. Tangke, "Halaman Sampul," Agrikan J. Agribisnis Perikan., vol. 9, no. 2, pp. 1-214, 2016, doi: 10.29239/j.agrikan.9.2.i-iii.

[14]D. Handayani, D. R. Hadi, F. Isbaniah, E. Burhan, and H. Agustin, “Corona Virus Disease 2019," J. Respirologi Indones. vol. 40, no. 2, pp. 119-129, 2020, doi: 10.36497/jri.v40i2.101.

[15]C. Sohrabi et al., "World Health Organization declares global emergency: A review of the 2019 novel coronavirus (COVID19)," Int. J. Surg., vol. 76, pp. 71-76, 2020, doi: 10.1016/j.ijsu.2020.02.034.

[16]K. Nishi, M. Demura, J. Miura, and S. Oishi, "Use of Thermal Point Cloud for Thermal Comfort Measurement and Human Pose Estimation in Robotic Monitoring," Proc. - 2017 IEEE Int. Conf. Comput. Vis. Work. ICCVW 2017, vol. 2018-Janua, pp. 1416-
1423, 2017, doi: 10.1109/ICCVW.2017.168

[17]Z. Zhang, "Microsoft kinect sensor and its effect," IEEE Multimed., vol. 19, no. 2, pp. 4-10, 2012, doi: 10.1109/MMUL.2012.24.

[18]A. L. I. Uroidhi, "Sistem Pemetaan Menggunakan Fitur Depth Sensor Kinect Pada Mobile Robot Untuk Proses Evakuasi Kebakaran Gedung Sistem Pemetaan Menggunakan Fitur Depth Sensor Kinect Pada Mobile Robot," 2017.

[19]I. Prasetyanto, C. Darujati, and A. B. Gumelar, "Deteksi Wajah Dengan Pemindai Kinect XBOX 360 Menggunakan Microsoft Kinect SDK dan WPF C\#," Semin. Nas. Fak. Tek. - SNFT V 2015, no. September 2015, 2015.

[20]N. Smolyanskiy, C. Huitema, L. Liang, and S. E. Anderson, "Real-time 3D face tracking based on active appearance model constrained by depth data," Image Vis. Comput., vol. 32, no. 11, pp. 860-869, 2014, doi: 10.1016/j.imavis.2014.08.005.

[21]E. Rahmawati, "Rekonstruksi Wajah Manusia Dalam Bentuk Tiga Dimensi Menggunakan Metode Partial Defferential Equations Dan," vol. 18, no. 1, pp. 28-33, 2013.

[22]T. Guzsvinecz, V. Szucs, and C. Sik-Lanyi, "Suitability of the kinect sensor and leap motion controller-A literature review," Sensors (Switzerland), vol. 19, no. 5, 2019, doi: 10.3390/s19051072.

[23]P. Krishnan and S. Naveen, "RGB-D face recognition system verification using kinect and FRAV3D databases," Procedia Comput. Sci., vol. 46, no. Icict 2014, pp. 1653-1660, 2015, doi: 10.1016/j.procs.2015.02.102.

[24]K. Fong and J. Zhang, "Ir-Depth Face Detection and Lip Localization Using," no. 9, pp. 24-30, 2015.

DOI: https://doi.org/10.29207/resti.v6i1.3687 